\title{
UPAYA PENINGKATAN PRESTASI BELAJAR SISWA PADA KOMPETENSI PERKEMBANGAN KOLONIALISME DAN IMPERIALISME BARAT MELALUI FILM STRIP DALAM PEMBELAJARAN PPKn
}

\author{
Hanim \\ Sekolah Menengah Pertama Negeri 38 Medan \\ hanim@gmail.com
}

\begin{abstract}
Abstrak: Penelitian ini bertujuan: mengetahui kelancaran proses pembelajaran PPKn yang dilakukan dengan model pembelajaran tipe TGT, mengetahui sejauh mana minat dan kemauan siswa dalam belajar PPKn dengan dilakukannya pembelajaran model tipe TGT, mengetahui seberapa besar tingkat prestasi hasil belajar PPKn siswa dengan menerapkan pembelajaran model tipe TGT. Hasil penelitian menunjukkan: (1) Hasil pembelajaran siswa dengan menerapkan model pembelajaran tipe TGT telah terjadi peningkatan secara signifikan. Sebelum dilaksanakan tindakan kelas nilai rata-rata mata pelajaran PPKn siswa adalah 56,130 dengan kategori rendah. Setelah dilakukan tindakan kelas pada siklus I nilai hasil belajar siswa rataratanya menjadi 74,63 dan standar deviasi 10,88 (kategori sedang). Pada siklus II rata-rata hasil belajar siswa terjadi peningkatan yaitu 80,75 berada pada kategori baik dengan simpangan bakunya 7,72; (2) Sebelum dilakukan tindakan kelas, tingkat ketuntasan belajar adalah 22,5\%. Pada siklus I setelah dilakukan tindakan maka ketuntasan siswa menjadi $80 \%$. Pada siklus ke 2 setelah dilaksanakan tindakan lebih lanjut sebagai hasil dari refleksi siklus I presentase tingkat ketuntasan siswa menjadi 95 \%; (3) Keaktifan siswa dalam mengikuti pembelajaran PPKn setelah dilakukan tindakan kelas pada siklus I dan siklus II semakin meningkat. Pada siklus I rata-rata kehadiran siswa 95,5 \% dan pada siklus II kehadiran siswa menjadi 98,5 $\%$.
\end{abstract}

Kata Kunci: perkembangan kolonialisme dan imperialisme barat, film strip, PPKn

\begin{abstract}
This study aims: to determine the smoothness of the PPKn learning process which is carried out with the TGT type learning model, to determine the extent of students' interest and willingness in learning PPKn by doing the TGT type learning model, to find out how much the level of achievement of student PPKn learning outcomes by applying the learning model type TGT. The results showed: (1) The learning outcomes of students by applying the TGT type of learning model had increased significantly. Before the class action was carried out, the average value of the students' PPKn subjects was 56.130 in the low category. After the classroom action was carried out in the first cycle, the average student learning outcomes were 74.63 and a standard deviation of 10.88 (moderate category). In the second cycle the average student learning outcomes increased, namely 80.75 in the good category with a standard deviation of 7.72; (2) Prior to the classroom action, the level of learning completeness was $22.5 \%$. In the first cycle after the action was taken, the students' completeness became $80 \%$. In the second cycle, after further action was carried out as a result of the reflection of the first cycle, the percentage of students' completeness level became 95\%; (3) The activeness of students in participating in PPKn learning after class action in cycle I and cycle II increases. In the first cycle the average student attendance was $95.5 \%$ and in the second cycle the attendance was $98.5 \%$.
\end{abstract}

Keywords: development of western colonialism and imperialism, film strip, PPKn

\section{PENDAHULUAN}

Pada masa sekarang ini tuntutan dunia pendidikan mengharuskan guru memiliki kemampuan untuk mendesain proses pembelajaran yang baik dan efektif dengan berorientasi pada peningkatan mutu siswa sehingga rumusan tujuan yang telah direncanakan oleh guru selaku perancang pembelajaran dapat tercapai secara maksimal. Slaah satu kemampuan yang harus dikuasai guru adalah melakukan desain proses pembelajaran yang mengedepankan aktifitas dan keterlibatan siswa di dalam kelas.
Menyikapi kegiatan pembelajaran di dalam kelas, guru harus mampu merangsang keterlibatan aktif dan kreatifitas siswa, sehingga proses pembelajaran dapat berjalan dengan dinamis dan menyenangkan. Untuk merangsang aktifitas dan kreatifitas para siswa, guru dituntut untuk mengurangi model dan strategi pembelajaran yang monoton. Guru harus menggantinya dengan model dan strategi pembelajaran yang aktif (active learning) dengan mengkombinasikan beberapa strategi pembelajaran yang dapat merangsang aktifitas dan kreatifitas siswa di dalam kelas. 
Mata pelajaran PPKn merupakan salah satu mata pelajaran yang penting di SMP. Karena mata pelajaran ini sangat berhubungan dengan kehidupan manusia sehari-hari. Tanpa mengenal PPKn maka kita tidak dapat mengenal alam, teknologi tidak akan berkembang jika tidak ada mata pelajaran PPKn. Sejalan dengan kondisi yang dikemukakan di atas kiranya perlu dikembangkan model pembelajaran PPKn yang dapat meningkatkan hasil belajar siswa melalui penerapan pengetahuan, melakukan pemcehan masalah, berkerja sama secara demokratis dan saling menolong baik untuk dirinya sendiri dan untuk orang lain. Sehingga metode yang tepat adalah model pembelajaran Kooperatif tipe TGT (Team Games Tournament) yang akan dijadikan penelitian dalam tulisan ini.

Model pembelajaran tipe TGT digolongkan kepada model pembelajaran secara kooperatif. Model Kooperatif (Cooperative Learning) dikembangkan berdasarkan teori belajar kognitif/konstruktivis. Salah satu terori Vygotsky, yaitu tentang penekanan pada hakekat sosio-kultural dari pembelajaran. Model pembelajaran kooperatif (cooperative learning) dikembangkan dalam rangka untuk meningkatkan aktifitas bersama sejumlah siswa dalam satu kelompok selama pembelajaran berlangsung. Aktifitas pembelajaran kooperatif menekankan pada kesadaran siswa untuk belajar berfikir, memecahkan masalah sebagai aplikasi dari pengetahuan dan keterampilan dan satu sama lainnya saling berbagi pengetahuan konsep, keterampilan kepada siswa lain yang membutuhkan. Dengan kata lain dalam pembelajaran kooperatif siswa saling tolong menolong dan bekerja sama untuk memecahkan masalah yang dihadapinya.

\section{Pemahaman Tentang Pembelajaran}

Pembelajaran merupakan proses
interaksi antara peserta didik dengan lingkungan belajar (termasuk guru). Hanya saja pembelajaran yang dilakukan tanpa mengindahkan aktifitas siswa dengan pola lama masih banyak terjadi. Situasi pembelajaran seperti ini tentu saja menciptakan suasana kelas yang statis dan membosankan. Bahkan yang lebih memprihatikan lagi akan mematikan aktifitas dan kreatifitas siswa. Model pembelajaran seperti ini dikenal dengan nama "Banking Concept Learning". Dalam hal ini siswa diberikan berbagai pengetahuan dan informasi oleh guru begitu saja, kemudian siswa dianggap sebagai objek penampung wawasan pegetahuan guru, yang hasilnya akan dapat dilihat setelah proses pembelajaran berlangsung.

Menurut Purwanto (1990), "Belajar merupakan perubahan yang terjadi melalui latihan dan pengalaman, dalam arti perubahanperubahan yang disebabkan oleh pertumbuhan dan kematangan tidak dianggap sebagai hasil belajar, seperti perubahan-perubahan yang terjadi pada seorang bayi. Untuk dapat disebut belajar, maka perubahan itu harus relative mantap, harus merupakan akhir dari suatu oeriode yang cukup panjang. Berapa lama periode itu berlangsung sulit ditentukan dengan pasti, tetapi perubahan itu hendaknya merupakan akhir dari suatu periode yang mungkin berlangsung berhari-hari, berbulanbulan, bahkan bertahun-tahun. Berarti kita harus mengabaikan perubahan tingkah laku yang disebabkan oleh motivasi, kelelahan, adaptasi, ketajaman perhatian, atau kepekaan seseorang yang biasanya hanya berlangsung sementara. Tingkah laku yang mengakhiri perubahan karena belajar menyangkut berbagai aspek kepribadian, baik fisik maupun psikis, seperti perubahan dalam pengertian, pemecahan masalah, keterampilan, kecapakan, kebiasaan ataupun sikap sehari-hari".

Pengertian mengajar menurut Ibrahim dan Syaodin (2003) menyatakan "Mengajar dalam arti sempit diartikan sebagai proses penyampaian pengetahuan kepada siswa. Dalam pengertian yang lebih luas, mengajar mencakup segala kegiatan menciptakan situasi agar para siswa dapat belajar. Pengertian belajar cukup luas, mencakup uapaya guru mendorong siswa agar belajar, menata ruang, atau tempat duduk siswa, menglompokkan siswa, mencipatakan berbagai kegiatan kelompok, memberikan berbagai bentuk tugas dan kegiatan siswa".

Kegiatan pembelajaran sesungguhnya tidak terlepas dari kegiatan belajar mengajar. Di satu sisi siswa melakukan kegiatan belajar karena guru memberikan pelajarannya (mengajar), sebaliknya guru pun mengajar karena anak didiknya memang mau belajar. Oleh karena itu keduanya tidak dapat dipisahkan, satu sama lainnya harus saling berbarengan dan saling isi mengisi. Pendekatan atau metode mengajar dari guru sangat menentukan keberhasilan siswa dalam proses pembelajaran. 


\section{Pembelajaran PPKn}

Hendaknya dapat disadari bahwa belajar merupakan proses pendewasaan diri, dengan belajar maka manusia akan dapat mengenal diri dan lingkungannya. Belajar PPKn merupakan suatu keharusan bagi manusia, karena ilmu PPKn merupakan ilmu yang sangat penting dan sangat berguna dalam kehidupan sehari-hari. Sejalan dengan jalan konstruktivisme, Syahrul (2008, 12) menyatakan bahwa "belajar PPKn tidak dapat disamakan dengan menuangkan air ke dalam botol, semakin diisi dengan tumpahan air yang berlebihan megakibatkan air tidak dapat masuk ke dalam botol.

PPKn adalah ilmu deduktif, aksiomatik, format, hirarckis, abstrak, memiliki Bahasa simbul yang padat arti. Sehingga para ahli matematika dapat mengembangkan sebuah system PPKn Mengingat adanya perbedaan karakteristik tersebut, maka diperlukan adanya kemampuan khusus dari seorang guru untuk menjembatani antara dunia anak yang belum berpikir secara deduktif untuk dapat mengerti dunia PPKn yang sebenarnya. Menurut Karsono (2007) "Dari dunia PPKn yang merupakan sebuah system yang deduktif telah mampu mengembangkan model-model yang merupakan contoh dari system-sistem itu. Model-model matematika sebagai suatu interpretasi dari system PPKn ini kemudian ternyata dapat digunakan untuk mengatasi persoalan-persoalan dunia nyata. Manfaat lain yang menonjol adalah deengan PPKn dapat membentuk pola piker orang yang mempelaarinya menjadi pola piker PPKn yang sistematis, logis, kritis dengan penuh kecermatan. Namun sayangnya pengembangan system atau model PPKn itu tidak selalu sejalan dengan perkembangan berpikir anal".

Baangkali dari pandangan ini, maka seorang siswa akan dapat memahami PPKn hanya apabila siswa tersebut secara aktif mengkonstruksikan pengetahuan yang dimilikinya lewat pengalaman dengan lingkungannya. Dalam pembelajaran aktif siswa dapat berpartisipasi aktif sedemikian sehingga kegiatan siswa dalam belajar jauh lebih dominan dari kegiatan guru-guru dalam mengajar.

\section{Model Pembelajaran Kooperatif}

Pembelajaran kooperatif (Cooperative Learning) merupakan salah satu metode atau model pembelajaran yang saat ini sedang dikembangkan. Menurut Tarigan (1999), "Pembelajaran kooperatif adalah merupakan strategi belajar mengajar dimana siswa belajar dalam kelompok kecil yang memiliki tingkat kemampuan yang berbeda dengan menyelesaikan tugas kelompok dimana setiap anggota saling bekerja sama dalam membantu untuk memahami suatu bahan pembelajaran". Model pembelajaran kooperatif membagi setiap siswa dalam kelompok kecil dengan tingkat kemampuan yang berbeda, menggunakan kegiatan belajar yang bervariasi untuk meningkatkan pemahaman siswa terhadap topik/materi yang diajarkan. Setiap anggota kelompok bertanggung jawab untuk mempalajari materi yang sedang diajarkan, tetapi juga bertanggung jawab untuk membantu anggota kelompok belajarnya, dengan demikian perlu diciptakan atmosfer keberhasilan.

Tujuan model pembelajaran kooperatif adalah :

1. Belajar akademik

2. Penerimaan terhadap keragaman

3. Pengembangan keterampilan social

Abdurrahman (1999), mengemukakan terdapat 4 (empat) unsur dalam pembelajaran kooperatif, yaitu :

1. Saling ketergantungan positif

2. Interaksi tatap muka

3. Akuntabilitas (Peranan Individu)

4. Keterampilan menjalin hubungan interpersonal

Selanjutnya, Ibrahim (2000) mengemukakan langkah-langkah dalam pembelajaran kooperatif, yaitu :

1. Menyampaikan tujuan dan memotivasi siswa. Guru menyampaikan semua tujuan pembelajaran yang ingin dicapai pada pelajaran tersebut dan memotivasi siswa untuk belajar.

2. Menyajikan informasi. Guru menyajikan informasi kepada siswa dengan jalan demokrasi atau dengan bahan bacaan.

3. Mengorganisasikan siswa ke dalam kelompok belajar. Guru menjelaskan kepada siswa bagaimana caranya membentuk kelompok belajar dan membantu setiap kelompok agar melakukan transisi secara efisien.

4. Membimbing kelompok bekerja dan belajar. Guru membimbing kelompok belajar pada saat mereka mengerjakan tugas-tugas.

5. Evaluasi. Guru mengevaluasi hasil belajar tentang materi yang telah dipelajari atau 
masing-masing

kelompok

mempresentasikan hasil kerjanya.

6. Memberikan penghargaan atau reward. Guru mencari cara untuk memberikan penghargaan hasil belajar baik secara individu ataupun kelompok.

\section{Pembelajaran Model Kooperatif Tipe TGT}

Salah satu model pembelajaran kooperatif adalah tipe TGT (Team Gamers Tournament), yaitu suatu tipe pembelajaran kooperatif untuk mendorong siswa saling membantu dan memotivasi serta menguasai keterampilan yang dibentuk oleh guru. Dalam pembelajaran kooperatif tipe TGT siswa dalam suatu kelas tertentu dibagi menjadi kelompok dengan anggota beberapa orang. Setiap kelompok haruslah heterogen, terdiri dari lakilaki dan perempuan, memeiliki kemampuan yang tinggi, sedang dan rendah. Guru menyiapkan permainan yang disiapkan dalam bentuk kartu soal, atau lembar kerja siswa. Pada akhir kegiatan pembelajaran yang dilaksanakan akan ditentukan pemenang.

Berdasarkan Depdiknas (2008), unsurunsur yang terdapat dalam model pembelajaran ini adalah :

1. Siswa dalam kelompoknya harusnya beranggapan bahwa mereka "sehidup dan sepenanggungan bersama".

2. Siswa bertanggung jawab atas segala sesuatu tindakan di dalam kelompoknya.

3. Siswa haruslah melihat bahwa semua anggota di dalam kelompoknya memiliki tujuan yang sama.

4. Siswa akan dikenakan evaluasi atau diberikan hadiah/penghargaan yang juga akan dikenakan untuk semua anggota kelompok.

5. Siswa berbagi kepemimpinan dan mereka membutuhkan keterampilan untuk belajar bersama selama proses belajarnya.

Sementara itu ciri-ciri yang dikemukakannya dalam model pembelajaran kooperatif tipe TGT ini antara lain adalah :

1. Siswa bekerja dalam kelompok secara kooperatif untuk menuntaskan materi belajarnya.

2. Kelompok dibentuk dari siswa yang memiliki kemampuan tinggi, sedang dan rendah.

3. Penghargaan diberikan pada tiap anggota kelompok yang mempunyai prestasi yang lebih baik.
Tujuan penelitian dan pengembangan ini adalah sebagai berikut: (1) mengetahui kelancaran proses pembelajaran PPKn yang dilakukan dengan model pembelajaran tipe TGT; (2) mengetahui sejauh mana minat dan kemauan siswa dalam belajar PPKn dengan dilakukannya pembelajaran model tipe TGT; dan (3) mengetahui seberapa besar tingkat prestasi hasil belajar PPKn siswa dengan menerapkan pembelajaran model tipe TGT.

\section{METODE}

Penelitian yang dilakukan ini merupakan Penelitian Tindakan Kelas. Penelitian ini dilaksanakan di SMP N 38 Medan. PTK yang dilakukan ini terdiri dari 2 siklus. Setelah kegiatan pada siklus I berlangsung diikuti oleh kegiatan pada siklus II, dimana tindakan yang dilakukan pada siklus II merupakan refleksi (cerminan) dari kegiatan pada siklus II. Kegiatan pada siklus I dilaksanakan selama 5 minggu atau 10 kali, sedangkan pada siklus II juga dilaksanakan selama 5 minggu dengan 10 kali pertemuan.

Kegiatan Siklus I:

Perencanaan Tindakan

a. Kegiatan pada siklus I rencana kegiatan tindakan dilaksanakan dengan terlebih dahulu merumuskan standar kompetensi. Kompetensi dasar menjadi indikator di dalam silabus menurut Kurikulum 2013.

b. Membuat Rencana Pembelajaran (RPP) sesuai dengan materi pembelajaran semester I dengan model pembelajran kooperatif, yang meliputi:

- Tujuan dari pembelajaran

- Deskripsi materi pembelajaran

- Metode atau model pembelajaran

- Strategi dan langkah-langkah pelaksanaan pembelajaran

- Menentukan sumber dan media pembelajaran dan penilaian

c. Mengembangkan alat bantu dan media pembelajaran yang sesuai dengan model pembelajaran kooperatif menurut pola sistem tipe TGT.

d. Menyiapkan kartu dalam permainan yang akan dilakukan oleh siswa dalam turnamen dari masing-masing team (regu/kelompok)

e. Membuat pedoman observasi melalui pengamatan terhadap kegiatan siswa di dalam kelas.

f. Membuat alat evaluasi untuk melakukan penilaian terhadap siswa. 
Pelaksanaan Tindakan

Pada siklus I pelaksanaan tindakan kelas yang dilakukan meliputi:

a. Mengidentifikasi keadaan siswa berupa minat dan kesiapannya dalam pembelajaran dengan terlebih dahulu melakukan tes awal sebelum kegiatan dilaksanakan.

b. Membahas materi pelajaran dengan menerapkan model pembelajaran kooperatif tipe TGT.

c. Membagi kelompok siswa, dimulai dengan kelompok/team yang terdiri dari 4 orang siswa dan setiap team diberikan nama.

d. Memeberikan tugas masing-masing kelompok sesuai dengan bahan/materi yang diberikan. Kemudian siswa melakukan aktifitas sesuai dengan tingkat kelompok yang telah ditetapkan.

e. Setelah melaksanakan aktifitas pembelajaran kepada siswa dilakukan tes akhir (siklus I) untuk mengetahui tingkat prestasi yang dimiliki setelah dilakukan tindakan kelas dengan model pembelajaran tipe TGT.

Pengamatan (Observasi)

Selama berlangsung pembelajaran di dalam kelas dengan menerapkan pembelajaran tipe TGT. Observer, yaitu guru PPKn lain melakukan pengamatan hal-hal yang terjadi, apa saja kegiatan yang dilakukan siswa. Apakah sudah sesuai dengan yang direncanakan sebelumnya. Disamping itu peneliti sebagai guru pembimbing bertindak bertindak juga sebagai pengamal (observer).

\section{Refleksi}

Refleksi dari penenlitian tindakan kelas pada siklus ini dimaksudkan untuk meningkatkan kemampuan siswa dalam melakukan kerjasama kelompok dalam memecahkan berbagai masalah yang dihapadi dalam mata pelajaran PPKn. Dari data-data yang diperoleh dari hasil observasi dikumpulkan dan dianalisa, sehingga dapat disimpulkan langkah-langkah yang akan diambil dalam siklus berikutnya.

\section{Kegiatan Siklus II:}

Kegiatan yang dilakukan pada siklus ke II tidak jauh berbeda dengan kegiatan pada sikluk I, dimana dilakukan perbaikan dan penambahan kegiatan yang dirasa perlu setelah mengevaluasi kegiatan pada siklus I.

Kegiatan-kegiatan yang dilakukan pada siklus II ini adalah sebagai berikut:
1. Berdasarkan hasil refleksi pada siklus I dirumuskan tindakan yang akan dilaksanakan pada siklus II.

2. Melakukan pelaksanaan tindakan kelas.

3. Melakukan analisa dari hasil kegiatan.

4. Refleksi terhadap kegiatan.

5. Pada akhir kegiatan dilaksanakan juga tes akhir (siklus II).

\section{Metode Pengumpulan Data}

Ada beberapa teknik pengumpulan data dalam penelitian ini, yaitu berupa tes awal pada awal kegiatan penelitian, tes akhir dilaksanakan sebanyak 2 kali yaitu setelah selesai kegiatan pada siklus I dan akhir kegiatan pada siklus II. Melakukan observasi melalui lembar pengamatan pada setiap kegiatan, dan berupa tanggapan dari siswa terhadap kegiatan atau metode yang dilakukan dalam pembelajaran.

Pemberian tes terhadap siswa dimaksudkan untuk mengetahui hasil belajar siswa sebelum dan sesudah tindakan dilaksanakan. Selama proses belajar berlangsung siswa diamati dengan mengisi lembar pengamatan (observasi), sejauh mana aktivitas dan kreativitas siswa dalam mengikuti pembelajaran. Demikian pula khusus tentang kehadiran siswa, dilakukan absensi kegiatan, sehingga dapat diketahui presentase kehadiran pada setiap siklus.

\section{Metode Analisis Data}

Teknik analisis data dalam penelitian ini dilakukan dengan teknik analisis kualitatif dan kuantitatif. Analisis kuantitatif seperti biasanya dilakukan dengan menggunakan statistik deskriptif. Sementara untuk analisis kualitatif data diperoleh dengan membuat data kategori (pengelompokkan data berdasarkan mastery level) sesuai dengan sistem penilaian yang berlaku dalam Kurikulum di SMP N 38 Medan, untuk mata pelajaran PPKn adalah sebagai berikut :

- KKM adalah 70.

- Tingkat penguasaan diatas 89\% dikategorikan Sangat Tinggi.

- Tingkat penguasaan dari 80 s/d $89 \%$ dikategorikan Tinggi.

- Tingkat penguasaan dari 70 s/d 79\% dikategorikan Sedang.

- Tingkat penguasaan $70 \%$ merupakan Mastery Level (KKM)

- Tingkat penguasaan dari 36 s/d 69\% dikategorikan Rendah. 
- Tingkat penguasaan dibawah $36 \%$ dikategorikan Sangat Rendah.

Analisis data untuk tes awal dan tes akhir pada setiap siklus dalam penelitian ini dilakukan dengan menggunakan software program analisis butir soal "Excel". Program ini dapat berfungsi untuk menganalisis perangkat soal pilihan berganda dan soal uraian.

Input data dilakukan dengan langkah-langkah sebagai berikut :

a. Isikan ke dalam format data pemeriksaan siswa nama sekolah, mata pelajaran yang diujikan, semester, tanggal ujian, tanggal diperiksa, materi soal, jenis ujian, nama, dan NIP pembuat soal, jumlah butir soal, skor tiap soal dan kunci jawaban.

b. Tulis nama siswa secara berurutan serta jawaban (option) yang dipilih siswa dengan huruf kapital, bila ada jawaban yang kosong tuliskan dengan huruf $\mathrm{F}$ atau $\mathrm{G}$, atau $\mathrm{H}$ dan seterusnya.

c. Pada kolom yang disediakan jangan lupa tuliskan batas kelulusan (mastery level) atau KKM dari KD/ SK atau mata pelajaran yang diujikan.

d. Input data selesai. Hasil atau output yang diperoleh berupa hasil data, proses data, analisis butir soal dan raport.

Dari analisis ini dapat diketahui antara lain rata-rata, simpangan baku, nilai tertinggi, nilai terendah, nilai diatas rata-rata, nilai dibawah rata-rata, jumlah siswa yang tuntas dan belum tuntas.

\section{Indikator Kinerja}

Adapun yang menjadi indikator kinerja sebagai keberhasilan dalam penelitian tindakan kelas ini adalah terjadinya perubahan keaktifan siswa dalam proses pembelajaran serta kenaikan hasil belajar siswa secara rata-rata. Hal ini akan dapat dilihat setelah dilakukannya tindakan kelas.

Indikator kinerja dalam penelitian ini dikatakan berhasil apabilaterjadi peningkatan prestasi belajar dengan tindakan yang dilakukan pada setiap siklus. Hal ini dapat dilihat dari nilai rata-rata tes awal dan tes akhir siklus I maupun siklus II. Demikian pula perubahan tingkah laku dan aktifitas siswa pada setiap siklus terjadi peningkatan yang berarti.

\section{HASIL DAN PEMBAHASAN}

Gambaran hasil penelitian secara umum menunjukkan hasil yang sangat menggembirakan. Setelah dilakukan tindakan kelas berupa penerapan model kooperatif tipe TGT. Hasil belajar PPKn dari siswa kelas VI menunjukkan peningkatan yang signifikan, demikian pula peningkatan perubahan keaktifan siswa dalam mengikuti proses belajar mengajar. Disamping itu pemahaman siswa tentang belajar PPKn khususnya dengan pembelajaran model pembelajaran tipe TGT semakin meningkat. Hal ini ditandai dengan pendapat para siswa tentang betapa pentingnya model tipe TGT ini untuk dikembangkan dalam pembelajaran PPKn di SMP N 38 Medan.

\section{Analisis Deskriptif Hasil Pada Tes Awal}

Pada awal kegiatan, yaitu pada siklus I dilaksanakan tes awal yang merupakan ulangan harian dari beberapa rangkaian materi yang telah diajarkan. Sebagai hasil analisis deskriptif terhadap nilai yang diperoleh siswa dapat disajikan pada Tabel 1.

Tabel 1. Statistik Hasil Belajar Pada Tes Awal

\begin{tabular}{|l|l|c|}
\hline No & \multicolumn{1}{|c|}{ Statistik } & $\begin{array}{c}\text { Angka } \\
\text { Statistik }\end{array}$ \\
\hline 1 & Jumlah Siswa & 40 \\
\hline 2 & $\begin{array}{l}\text { Kriteria Ketuntasan } \\
\text { Minimal }\end{array}$ & 70 \\
\hline 3 & Tuntas & 9 \\
\hline 4 & Belum Tuntas & 31 \\
\hline 5 & Nilai Tertinggi & 75 \\
\hline 6 & Nilai Terendah Nilai & 35 \\
\hline 7 & $\begin{array}{l}\text { Rentang } \\
\text { (Jangkauan) }\end{array}$ \\
\hline 8 & Rata-Rata (Mean) & 56,125 \\
\hline 9 & Simpangan Baku & 12,531 \\
\hline
\end{tabular}

Seperti yang terlihat pada Tabel 1 menunjukkan bahwa hasil belajar matematika yang diperoleh siswa pada tes awal memiliki nilai rata-rata adalah 56,125 dan standar deviasi adalah 12,531. Siswa yang tuntas sebanyak 9 orang, sedangkan yang belum tuntas ada sebanyak 31 orang dari 40 orang jumlah siswa yang ada. Nilai tertinggi perolehan siswa 75 dan nilai terendah 35, KKM mata pelajaran PPKn adalah 70 .

Dari data diatas bila nilai hasil belajar matematika tersebut dikelompokkan berdasarkan kategori (tingkatan), maka diperoleh distribusi nilai seperti yang disajikan pada Tabel 2.

Tabel 2. Distribusi Frekuensi dan Presentase Penguasaan Siswa Pada Tes Awal 


\begin{tabular}{|l|l|c|c|}
\hline $\begin{array}{l}\text { Rentan } \\
\text { g Nilai }\end{array}$ & Kategori & $\begin{array}{c}\text { Frekuensi } \\
\text { (Orang) }\end{array}$ & $\begin{array}{c}\text { Presentas } \\
\text { e (\%) }\end{array}$ \\
\hline $\begin{array}{l}0-35 \\
36-69\end{array}$ & $\begin{array}{l}\text { Sangat } \\
\text { Rendah } \\
\text { Rendah }\end{array}$ & 5 & 12,5 \\
& $\begin{array}{l}\text { Tidak } \\
\text { Tuntas }\end{array}$ & 31 & 77,5 \\
\hline $70-79$ & Sedang & 9 & 22,5 \\
$80-89$ & $\begin{array}{l}\text { Tinggi } \\
90\end{array}$ & 0 & 0 \\
100 & $\begin{array}{l}\text { Sangat } \\
\text { Tinggi }\end{array}$ & 0 & 0 \\
\hline & Tuntas & 9 & 22,5 \\
\hline & $\begin{array}{l}\text { Nilai } \\
\text { Diatas } \\
\text { Rata-Rata }\end{array}$ & 17 & 42,5 \\
\hline & $\begin{array}{l}\text { Nilai } \\
\text { Dibawah } \\
\text { Rata-Rata }\end{array}$ & 23 & 57,5 \\
\hline & TOTAL & 40 & 100 \\
\hline
\end{tabular}

Dari Tabel 2 menunjukkan bahwa ratarata penguasaan belajar siswa berada pada kategori rendah 56,125 dan dibawah nilai KKM. Dengan tingkat ketuntasan 22,5\%, artinya siswa yang sudah tuntas belajar hanya 9 orang saja, sedangkan yang belum tuntas ada sebanyak 31 orang $(77,5 \%)$. Siswa yang memiliki nilai diatas rata-rata ada sebanyak 17 orang $(42,5 \%)$ dan nilai di bawah rata-rata sebanyak 23 orang $(57,5 \%)$.

\section{Analisis Deskriptif Hasil Tes Akhir Pada Siklus I :}

Setelah selesai materi dengan 10 kali pertemuan dilaksanakan tes akhir untuk mengetahui hasil belajar siswa setelah dilakukan tindakan pada siklus I. Sebagai hasil analisis deskriptif nilai perolehan siswa dapat dilihat pada Tabel 3 .

Tabel 3. Statistik Nilai Hasil Belajar Siswa Pada Siklus I

\begin{tabular}{|l|l|c|}
\hline No & Statistik & $\begin{array}{c}\text { Angka } \\
\text { Statistik }\end{array}$ \\
\hline 1 & Jumlah Siswa & 40 \\
\hline 2 & $\begin{array}{l}\text { Kriteria Ketuntasan } \\
\text { Minimal }\end{array}$ & 70 \\
\hline 3 & Tuntas & 32 \\
\hline 4 & Belum Tuntas & 8 \\
\hline 5 & Nilai Tertinggi & 90 \\
\hline 6 & Nilai Terendah & 55 \\
\hline 7 & Rentang Nilai (Jangkauan) & 47 \\
\hline 8 & Rata-Rata (Mean) & $\mathbf{7 4 , 6 3 0}$ \\
\hline 9 & Simpangan Baku & 10,883 \\
\hline
\end{tabular}

Dari Tabel 3 menunjukkan bahwa nilai rata-rata siswa adalah 74,630. Nilai tertinggi 90 dan nilai terendah 55 dengan rentang nilai 47 , dan simpangan bakunya adalah 10,883. Pada siklus I ini siswa yang sudah tuntas menjadi 32 orang. Dalam hal ini terjadi peningkatan setelah dilakukan tindakan kelas sedangkan yang belum tuntas tinggal 8 (delapan) orang saja.

Bila nilai penguasaan siswa seperti yang ditunjukkan pada Tabel 3 dapat dikelompokkan ke dalam kategori, maka distribusi frekuensi dan presentase nilai penguasaan siswa dapat diperlihatkan pada Tabel 4 berikut.

Tabel 4 . Distribusi Frekuensi dan Presentase Penguasaan Siswa Pada Siklus I

\begin{tabular}{|c|c|c|c|}
\hline $\begin{array}{l}\text { Rentang } \\
\text { Nilai }\end{array}$ & Kategori & $\begin{array}{l}\text { Frekuens } \\
\mathrm{i} \text { (Orang) }\end{array}$ & $\begin{array}{c}\text { Presentas } \\
\text { e }(\%)\end{array}$ \\
\hline \multirow{3}{*}{$\begin{array}{l}0-35 \\
36-69\end{array}$} & Sangat & 0 & 0 \\
\hline & $\begin{array}{l}\text { Rendah } \\
\text { Rendah }\end{array}$ & 8 & 20 \\
\hline & $\begin{array}{l}\text { Tidak } \\
\text { Tuntas }\end{array}$ & 8 & 20 \\
\hline \multirow{7}{*}{$\begin{array}{l}70-79 \\
80-89 \\
90-100\end{array}$} & Sedang & 9 & 225 \\
\hline & Tinggi & 20 & 50 \\
\hline & $\begin{array}{l}\text { Sangat } \\
\text { Tinggi }\end{array}$ & 3 & 7,5 \\
\hline & Tuntas & 32 & 22,5 \\
\hline & $\begin{array}{l}\text { Nilai } \\
\text { Diatas } \\
\text { Rata-Rata }\end{array}$ & 25 & 62,5 \\
\hline & $\begin{array}{l}\text { Nilai } \\
\text { Dibawah } \\
\text { Rata-Rata }\end{array}$ & 15 & 37,5 \\
\hline & TOTAL & 40 & 100 \\
\hline
\end{tabular}

Dari Tabel 4 menunjukkan bahwa nilai rata-rata penguasaan siswa pada siklus I berada pada kategori sedang (diatas nilai KKM). Setelah dilakukan tindakan ternya tidak ada lagi siswa yang berada pada kategori sangat rendah, hanya 8 orang $(20 \%)$ siswa lagi yang berada pada kategori rendah. Siswa yang tidak tuntas hanya 8 orang atau $20 \%$, dan siswa yang tuntas ada sebanyak 32 orang atau $80 \%$. Nilai diatas rata-rata $62,5 \%$ (25 orang) sedangkan untuk nilai dibawah rata-rata $37,5 \%$ (15 orang).

\section{Analisis Deksriptif Hasil Tes Akhir Pada Siklus II}

Pada siklus II diperoleh analisis deskriptif nilai hasil belajar siswa, seperti yang disajikan pada Tabel 5 berikut. 
Tabel 5. Statistik Nilai Hasil Belajar Siswa Pada Siklus II

\begin{tabular}{|l|l|c|}
\hline No & Statistik & $\begin{array}{c}\text { Angka } \\
\text { Statistik }\end{array}$ \\
\hline 1 & Jumlah Siswa & 40 \\
\hline 2 & $\begin{array}{l}\text { Kriteria Ketuntasan } \\
\text { Minimal }\end{array}$ & 70 \\
\hline 3 & Tuntas & 38 \\
\hline 4 & Belum Tuntas & 2 \\
\hline 5 & Nilai Tertinggi & 95 \\
\hline 6 & Nilai Terendah Nilai & 60 \\
\hline 7 & $\begin{array}{l}\text { Rentang } \\
\text { (Jangkauan) }\end{array}$ & 37 \\
\hline 8 & Rata-Rata (Mean) & $\mathbf{8 0 , 7 5 0}$ \\
\hline 9 & Simpangan Baku & 7,725 \\
\hline
\end{tabular}

Dari Tabel 5 sebagai hasil belajar siswa pada siklus II ini menunjukkan peningkatan yang signifikan dimana nilai rata-ratanya menjadi 80,750, ada 9 orang yang memperoleh nilai tertinggi 90-95 dan nilai terndah 60, rentang nilai 37 sehingga simpangan bakunya menjadi 7,725. Pada siklus II ini setelah dilakukan tindakan sebagai hasil dari refleksi tindakan pada siklus I ternyata siswa yang tuntas sudah mencapai 38 orang atau $95 \%$ dan siswa yang tidak tuntas tinggal 2 orang atau 5 $\%$ saja.

Dari hasil belajar siswa seperti yang ditunjukkan pada Tabel 5 dapat dikelompokkan menjadi kategorisasi sebagai distribusi frekuensi dan presentasi nilai hasil belajar siswa pada siklus II, seperti yang ditunjukkan pada Tabel 6 berikut.

Tabel 6. Distribusi Frekuensi dan Presentase Nilai Penguasaan Siswa Pada Siklus II

\begin{tabular}{|c|c|c|c|}
\hline $\begin{array}{c}\text { Rentang } \\
\text { Nilai }\end{array}$ & Kategori & $\begin{array}{c}\text { Frekuensi } \\
\text { (Orang) }\end{array}$ & $\begin{array}{c}\text { Presentas } \\
\text { e }(\%)\end{array}$ \\
\hline \multirow{3}{*}{$\begin{array}{l}0-35 \\
36-69\end{array}$} & Sangat & 0 & 0 \\
\hline & $\begin{array}{l}\text { Rendah } \\
\text { Rendah }\end{array}$ & 2 & 5 \\
\hline & $\begin{array}{l}\text { Tidak } \\
\text { Tuntas }\end{array}$ & 2 & 5 \\
\hline \multirow{6}{*}{$\begin{array}{l}70-79 \\
80-89 \\
90-100\end{array}$} & Sedang & 8 & 20 \\
\hline & Tinggi & 22 & 55 \\
\hline & $\begin{array}{l}\text { Sangat } \\
\text { Tinggi }\end{array}$ & 8 & 20 \\
\hline & Tuntas & 38 & 95 \\
\hline & $\begin{array}{l}\text { Nilai } \\
\text { Diatas } \\
\text { Rata-Rata }\end{array}$ & 16 & 40 \\
\hline & Nilai & 24 & 60 \\
\hline
\end{tabular}

\begin{tabular}{|c|l|c|c|}
\hline $\begin{array}{c}\text { Rentang } \\
\text { Nilai }\end{array}$ & Kategori & $\begin{array}{c}\text { Frekuensi } \\
\text { (Orang) }\end{array}$ & $\begin{array}{c}\text { Presentas } \\
\text { e (\%) }\end{array}$ \\
\hline & $\begin{array}{l}\text { Dibawah } \\
\text { Rata-Rata }\end{array}$ & & \\
\hline & TOTAL & 40 & 100 \\
\hline
\end{tabular}

Dari Tabel 6 dapat dilihat bahwa tingkatan kategori hasil belajar siswa pada siklus II menunjukkan hasil yang cukup baik, dimana nilai rata-rata penguasaan belajar siswa sudah mencapai kategori tinggi (tingkat penguasaan $80,750 \%$ ). Sedangkan siswa berada pada kategori sedang berjumlah 8 orang (20 \%) demikian pula pada kategori tinggi berjumlah 22 orang (55\%), kategori sangat tinggi ada sebanyak 8 orang atau $20 \%$ ini menunjukkan prestasi yang cukup baik. Nilai diatas rata-rata ada sebanyak 16 orang atau 40 $\%$ dan nilai di bawah rata-rata ada sebanyak 24 orang atau $60 \%$.

Tingkat ketuntasan belajar siswa pada tes awal, tes akhir siklus I dan tes akhir siklus II dapat dilihat pada Tabel 7 berikut.

Tabel 7. Tingkat Ketuntasan Belajar Siswa

\begin{tabular}{|c|l|c|c|c|c|}
\hline $\begin{array}{l}\text { N } \\
\text { o }\end{array}$ & $\begin{array}{l}\text { Kegia } \\
\text { tan }\end{array}$ & $\begin{array}{c}\text { Juml } \\
\text { ah } \\
\text { Tunt } \\
\text { as }\end{array}$ & $\begin{array}{c}\text { Present } \\
\text { ase (\%) }\end{array}$ & $\begin{array}{c}\text { Juml } \\
\text { ah } \\
\text { Tida } \\
\mathrm{k} \\
\text { Tunt } \\
\text { as }\end{array}$ & $\begin{array}{c}\text { Present } \\
\text { ase } \\
(\%)\end{array}$ \\
\hline 1 & $\begin{array}{l}\text { Tes } \\
\text { Awal }\end{array}$ & 9 & 22,5 & 31 & 77,5 \\
\hline 2 & $\begin{array}{l}\text { Tes } \\
\text { Akhir } \\
\text { Siklus } \\
\text { I }\end{array}$ & 32 & 80 & 8 & 20 \\
\hline 3 & $\begin{array}{l}\text { Tes } \\
\text { Akhir } \\
\text { Siklus } \\
\text { II }\end{array}$ & 38 & 90 & 2 & 5 \\
\hline
\end{tabular}

Dari Tabel 7 dan diagram batang pada Gambar 1 menunjukkan tingkat ketuntasan belajar siswa yang terjadi peningkatan. Hasil tes akhir siswa yang tuntas hanya 9 orang, pada siklus I menjadi 32 orang dan pada siklus II siswa yang tuntas menjadi 38 orang. Hal ini menunjukkan prestasi belajar siswa setelah dilakukan tindakan kelas baik pada siklus I maupun siklus II terjadi peningkatan yang sangat signifikan.

Secara umum dapat disimpulkan bahwa hasil belajar siswa setelah dilakukan tindakan 
kelas khususnya penerapan model pembelajaran dengan power two dalam pelajaran PPKn di kelas VI telah terjai peningkatan yang sangat signifikan. Dimana presentase nilai rata-rata penguasaan siswa dari $56,125 \%$ (kategori kurang) meningkat menjadi 74,630\% (kategori sedang) pada siklus I dan meningkat lagi pada siklus II menjadi $80,750 \%$ (berada pada kategori tinggi).

Tingkat prestasi belajar siswa pada tes awal, tes akhir siklus I, dan tes akhir siklus II dapat dilihat pada Tabel 8 berikut.

Tabel 8. Tingkat Prestasi Belajar Siswa Siklus I dan Siklus II

\begin{tabular}{|l|l|l|l|l|}
\hline No & Statistik & $\begin{array}{l}\text { Tes } \\
\text { Awal }\end{array}$ & $\begin{array}{l}\text { Tes } \\
\text { Akhir } \\
\text { Siklus I }\end{array}$ & $\begin{array}{l}\text { Tes } \\
\text { Akhir } \\
\text { Siklus } \\
\text { II }\end{array}$ \\
\hline 1 & $\begin{array}{l}\text { Nilai Rata- } \\
\text { Rata }\end{array}$ & 56,125 & 74,630 & 80,750 \\
\hline 2 & $\begin{array}{l}\text { Nilai } \\
\text { Tertinggi }\end{array}$ & 75 & 90 & 95 \\
\hline 3 & $\begin{array}{l}\text { Nilai } \\
\text { Terendah }\end{array}$ & 35 & 55 & 60 \\
\hline
\end{tabular}

Tabel 8 menunjukkan gambaran prestasi siswa yang meningkat. Nilai tertinggi yang diperoleh pada tes awal adalah 75 , itupun hanya 1 orang, nilai tertinggi pada tes akhir siklus I adalah 90 dan nilai 95 pada akhir siklus II (ada sebanyak 1 orang). Demikian pula nilai terendah pada tes awal adalah 35 , pada tes akhir siklus I meningkat menjadi 55 dan pada akhir siklus II nilai terendah menjadi 60 .

\section{Perubahan Keaktifan Siswa}

Selama berlangsungnya penelitian yaitu pada siklus I dan siklus II, telah terjadi peningkatan hasil belajar siswa secara signifikan. Demikian pula perubahan keaktifan siswa dalam mengikuti proses pembelajaran. Perubahan ini telah dicatat melalui hasil observasi siswa selama berlangsungnya proses belajar mengajar melalui lembar pengamatan. Adapun perubahan tersebut pada siklus I dan siklus II adalah sebagai berikut:

1. Terjadinya perubahan keaktifan siswa untuk mengikuti pembelajaran PPKn. Pada awal pembelajaran siklus I masih banyak siswa yang tidak hadir, setelah dilakukan tindakan kelas dengan model tipe TGT ternyata siswa menjadi tertarik dan kehadirannya mengalami peningkatan.
2. Kesungguhan siswa dalam mengikuti pembelajaran pun semakin meningkat, hal ini ditandai dengan keseriusan para siswa dalam keaktifan memecahkan masalah (soal-soal) yang diberikan guru. Dengan memberikan tanggung jawab kelompok kepada siswa, mereka lebih bersungguhsungguh belajar dan berkompetensi dalam menyelesaikan soal-soal yang diberikan.

3. Keaktifan siswa dalam menjawab pertanyaan lisan juga semakin meningkat. Hal ini ditandai dengan meningkatnya jumlah siswa yang memberikan jawaban benar, pada siklus I siswa yang memberikan jawaban benar hanya 13 orang tetapi pada siklus II meningkat menjadi 37 orang. Suatu hal yang sangat menggembirakan sejumlah siswa secara berulang-ulang mengacungkan tangan untuk menjawab pertanyaan yang diberikan guru.

4. Demikian pula keaktifan siswa dalam menyelesaikan tugas rumah semakin meningkat. Hal ini ditandai dengan meningkatnya frekuensi siswa yang menyelesaikan tugas rumah tepat sesuai pada waktunya, dimana pada siklus I tercatat sebanyak 86 kali meningkat menjadi 152 kali pada siklus II.

5. Keaktifan siswa untuk tampil di dalam kelas menyelesaikan soal di papan tulis juga mengalami peningkatan. Para siswa mulai lebih percaya diri dan mempunyai kemampuan untuk menyelesaikan soalsoal yang diberikan. Pada siklus I hanya beberapa orang saja yang sanggup dan mampu menyelesaikan soal dengan baik (5 orang), tetapi pada siklus II ada sebanyak 25 orang yang mampu menyelesaikan soal secara baik dan cermat.

6. Perhatian siswa terhadap penggunaan buku pegangan (referensi) semakin meningkat. Pada siklus II para siswa banyak memiliki buku bacaan yang digunakan sebagai penunjang proses belajar mengajar.

7. Perubahan yang juga menggembirakan dalam keterlibatan siswa untuk berdiskusi dan bekerjasama dengan sesama teman dalam hal memecahkan masalah yang diberikan guru. Pada awal siklus II ini sebanyak $90 \%$ siswa secara aktif memecahkan persoalan melalui kelompoknya. 


\section{Refleksi Terhadap Pelaksanaan Tindakan Kelas Kegiatan Pada Siklus I :}

Sebelum dilaksanakan pembelajaran dengan penerapan model tipe TGT peneliti melakukan tes awal mata pelajaran matematika, yang materinya merupakan mata pelajaran yang sudah disampaikan oleh guru. Hal ini bertujuan untuk mengetahui sejauh mana kemampuan belajar siswa sebelum dilaksanakannya tindakan kelas. Disamping itu juga dilaksanakan wawancara terhadap sejumlah siswa yang diambil secara random (acak) tentang pelajaran PPKn, cara mengajar guru serta masukan dari siswa tentang kesenangan mereka dalam belajar.

Beberapa hal yang perlu diuangkap dalam proses tindakan kelas pada siklus I:

1. Pada pertemuan I guru menjelaskan tentang model kooperatif tipe TGT terhadap siswa, serta kiat-kiat yang digunakan siswa dalam menerapkan model pembelajaran tersebut.

2. Pada awal pertemuan para siswa belum terbiasa dengan model ini. Karena para siswa sangat terbiasa dengan cara konvensional, yaitu guru menerangkan di depan kelas sementara siswa mendengar. Guru memberikan contoh, siswa mencatat, guru memberikan soal sesuai dengan contoh kemudian siswa menjawab soalsoal yang diberikan guru.

3. Para siswa banyak yang merasa ragu dan canggung untuk mengemukakan pendapat dalam kerja kelompok yang diberikan. Sebagai realisasinya guru memberikan pengertian dan memotivasi siswa untuk berani mengemukakan pendapat dan jangan takut salah. Karena satu kesalahan akan dapat diperbaiki dengan beberapa kebaikan pula. Setelah tindakan dilakukan siswa mulai terbiasa dan kemudian tampil untuk mengemukakan pendapatnya, dalam hal ini terbatas pada beberapa siswa yang pintar saja.

4. Pada pertemuan ke lima barulah siswa mulai terbiasa mengikuti model tipe TGT. Disini guru memberikan beberapa strategi dan teknik, serta motivasi kepada para siswa agar lebih giat dan teliti.

5. Memasuki pertemuan ke delapan barulah pembelajaran menjadi lebih terarah, siswa sudah mampu memecahkan sendiri masalah-masalah yang ada, bahkan siswa dapat membuat contoh-contoh soal sendiri kemudian memecahkannya. Pada kesempatan ini para siswa sudah mempunyai kepercayaan diri, ditandai semakin banyaknya siswa yang tampil untuk menyelesaikan soal-soal yang diberikan.

6. Pada pertemua ke sepuluh dilaksanakan tes akhir kepada siswa untuk mengetahui sejauh mana kemampuan hasil belajar siswa setelah dilakukan tindakan kelas dengan penerapan model pembelajaran tipe TGT.

\section{Kegiatan Pada SIklus II :}

Apa yang dilaksanakan pada siklus I tidak jauh berbeda dilakukan pada kegiatan siklus II, namun dari evaluasi kegiatan pada siklus I dapat menjadi perbaikan dan pemantapan teknik dan cara dalam pemecahan masalah pada siklus Ii. Tindakan yang dilakukan pada siklus ke II ini memberikan keleluasaan kepada siswa sendiri untuk belajar bersama secara bergotong-royong. Tidak harus lagi dibantu oleh guru, sehingga pada siklus ini siswa telah mandiri dalam mengembangkan pembelajaran menurut mereka masing-masing.

Hasil yang dicapai siswa dalam siklus II ini menunjukkan peningkatan secara signifikan. Nilai rata-rata hasil belajar siswa pada siklus I adalah 74,630 berada pada kategori sedang yang kemudian meningkat menjadi 80,750 berada pada kategori tinggi. Sementara itu tingkat ketuntasan siswa pada siklus II dari 30 orang siswa tuntas 38 orang atau $95 \%$ dibandingkan dengan siklus I dari 40 orang siswa yang tuntas 32 orang ( $80 \%$ ), jadi masih ada 8 orang lagi $(20 \%)$ yang belum tuntas.

Perubahan tingkah laku siswa dalam pembelajaran PPKn pada siklus II ini pun semakin meningkat. Hal ini ditandai dengan meningkatnya kehadiran siswa dalam mengikuti proses belajar mengajar (lampiran I). Rata-rata kehadiran siswa pada kegiatan di siklus I adalah 95,5\% demikian pula aktifitas lainnya seperti keaktifan dalam kerja kelompok, memecahkan masalah, mengerjakan tugas-tugas secara baik dan tepat waktu, serta perilaku dalam keberanian mengemukakan pendapat. Dalam pembelajaran telah terjadi peningkatan kualitas mutu dan kemandirian siswa.

\section{Analisis Refleksi Siswa}

Analisis refleksi siswa dimaksudkan untuk mengetahui sejauh mana pendapat mereka tentang mata pelajaran PPKn, metode 
dan cara yang baik menurut mereka serta kebiasaan yang perlu diterapkan dalam pembelajaran. Dari hasil observasi, baik berupa angket yang diberikan secara langsung kepada siswa maupun hasil wawancara yang dilakukan dapat disimpulkan hal-hal sebagai berikut:

1. Pada umumnya siswa menyenangi belajar PPKn apabila guru yang mengajar pandai menyajikan pelajaran, dapat dimengerti oleh siswa dan tidak terlalu kejam.

2. Ada beberapa siswa yang kurang menyenangi mata pelajaran PPKn karena bagi mereka pelajaran ini sulit dipahami dan dicerna, banyak teori dan masalah yang sulit untuk dipecahkan.

3. Beberapa siswa memang benar-benar menyenangi mata pelajaran ini karena pelajaran ini sangat mendukung dan menuntut siswa untuk lebih teliti, bertindak aktif, berdisiplin dan mengikuti kaedahkaedah yang berlaku. Pada umumnya mereka adalah siswa yang aktif dalam pembelajaran dan mempunyai kecerdasan yang lumayan.

4. Siswa sangat senang kepada guru yang pandai mengembangkan metode mengajar, mampu membuat pembaharuan atau inovasi mengajar secara profesional. Tegasnya siswa senang kepada guru yang memiliki kemampuan (kompetensi) mengajar yang baik.

5. Para siswa akan bersikap aktif dan pro aktif dalam pembelajaran PPKn bila guru memberikan keleluasaan kepada siswa untuk memecahkan berbagai persoalan, tetapi harus dibarengi dengan konsep yang terarah dari guru.

\section{PENUTUP}

Adapun kesimpulan yang dapat diambil dalam penelitian ini adalah sebagai berikut:

1. Hasil pembelajaran siswa dengan mererapkan model pembelajaran tipe TGT telah terjadi peningkatan secara signifikan. Sebelum dilaksanakan tindakan kelas nilai rata-rata mata pelajaran PPKn siswa kelas VI adalah 56,130 dengan simpangan baku 12,531 (dengan kategori rendah). Setelah dilakukan tindakan kelas pada siklus I nilai hasil belajar siswa rata-ratanya menjadi 74,630 dan standar deviasi 10,883 (kategori sedang). Pada siklus II rata-rata hasil belajar siswa terjadi peningkatan yaitu 80,750 berada pada kategori baik dengan simpangan bakunya 7,725 .

2. Sebelum dilakukan tindakan kelas, tingkat ketuntasan belajar adalah 22,50\% (dari 40 orang siswa hanya 9 orang yang tuntas). Pada siklus I setelah dilakukan tindakan maka ketuntasan siswa menjadi $80 \%$ (32 orang yang tuntas dari 40 siswa). Pada siklus ke 2 setelah dilaksanakan tindakan lebih lanjut sebagai hasil dari refleksi siklus I presentase tingkat ketuntasan siswa menjadi $95 \%$.

3. Keaktifan siswa dalam mengikuti pembelajaran PPKn setelah dilakukan tindakan kelas pada siklus I dan siklus II semakin meningkat. Pada siklus I rata-rata kehadiran siswa 95,5\% dan pada siklus II kehadiran siswa menjadi 98,5 \%. Demikian pula dalam melakukan aktifitas pembelajaran telah terjadi perubahan tingkah laku yang cukup baik dan siswa menjadi lebih mandiri.

\section{DAFTAR PUSTAKA}

Abdurrahman. M, (1999), Pendidikan Bagi Anak Yang Berkesulitan Belajar, Rineka Cipta; Jakarta.

Ahmadi, (2002), Transformasi Pendidikan Memasuki Millenium III, Kanisius; Yogyakarta.

Arikunto, (2002), Dasar-Dasar Evaluasi Pendidikan, Bina Aksara; Jakarta.

Daryanto, (2006), "Pedoman Pengembangan Model-Model Pembelajaran Untuk SMP /SMK, DIrektorat PMPTK DEPDIKNAS, Jakarta.

Ibrahim. M, (2000), Pembelajaran Cooperatif, Surabaya Press, UNS, Surabaya.

Karsono, (2007), Pendidikan Matematika I, Pusat Penerbitan Universitas Terbuka, DEPDIKNAS; Jakarta.

Purwanto. N, (1990), Psikologi Pendidikan, PT Remaja RoSMP akarya; Bandung.

Syahrul. AR, (2006), Perbedaan Prestasi Hasil Belajar Antara Model Cooperatif Learning dan Metode Konvensional di Kelas X Semester I SMP Negeri 068005 Medan Tahun Pelajaran 2005/2006, SMP N 38 Medan; Medan.

Tarigan. R, (1999), Pembelajaran Kooperatif Type TGT, Balai Penerbit UNIMED; Medan. 